\title{
Reconstruction of a transmetatarsal amputation stump using a salvaged peroneal artery fasciocutaneous flap from the opposite leg: A case report
}

\author{
Chenicheri Balakrishnan MD, Gil Altman MD, Abdullah J Khalil MD
}

\begin{abstract}
C Balakrishnan, G Altman, AJ Khalil. Reconstruction of a transmetatarsal amputation stump using a salvaged peroneal artery fasciocutaneous flap from the opposite leg: A case report. Can J Plast Surg 2005;13(4):209-211.

During lower extremity amputation, the objective is to provide a functional residual limb that permits maximum patient mobility and independence. Preservation of length of the fore part of the foot using salvageable tissue from the amputated part in young patients prevents equines deformity and revision of amputation to a higher level. This can be achieved using tissue available from the amputated part. The spare part concept in reconstructive surgery should be integrated into the trauma algorithm to avoid additional donor site morbidity. Reported here is a young adult patient with crush injuries to both feet, which resulted in amputations. A fasciocutaneous flap raised from one extremity was used to facilitate transmetatarsal amputation stump length preservation of the other extremity.
\end{abstract}

Key Words: Spare part concept; Transmetatarsal amputation stump

T evel of amputation is critical among partial foot amputaLtions where the more proximal the amputation, the more disability it causes. It is often impossible to determine the amputation level of the foot in crush injuries, and secondary revision amputation with bone shortening is usually required. Amputation level is very critical in partial foot amputations in young patients and should be reconstructed with flaps rather than shortening the bone if there is insufficient soft tissue covering the stump (1). To obtain maximum function in transmetatarsal amputations, as much metatarsal length as possible is required to preserve the dorsiflexion of the ankle and to prevent equines deformity. The ideal stump should have a mobile soft tissue envelope with proper contouring of bone ends to absorb shear and direct forces and to maintain a comfortable interface with the prosthesis. Although various methods have been described to preserve length and promote primary wound healing, we report a case where a flap was salvaged from the amputated contralateral extremity and transferred using microvascular technique to cover the transmetatarsal amputation stump.

\section{CASE PRESENTATION}

A 23-year-old man presented to the emergency department following crush injuries to both feet while working in his yard. He sustained crush avulsion to the entire left foot to the ankle, and the distal foot on the right. He had a history of frostbite to
La reconstruction du moignon d'une amputation transmétatarsienne au moyen d'un lambeau fasciocutané d'artère péronière récupéré de la jambe opposée : Un rapport de cas

Pendant l'amputation de l'extrémité inférieure, l'objectif consiste à obtenir un membre résiduel fonctionnel qui assure la mobilité et l'indépendance maximales du patient. Chez les jeunes patients, la préservation de la longueur de la partie avant du pied à l'aide de tissu récupérable de la partie amputée permet d'éviter les malformations équines et la révision de l'amputation à un niveau plus élevé. Le concept de pièce de rechange en chirurgie reconstructive devrait être intégré à l'algorithme du traumatisme pour éviter la morbidité additionnelle au foyer du donneur. Est exposé le cas d'un jeune patient adulte ayant des lésions par écrasement aux deux pieds, qui ont provoqué des amputations. Un lambeau fasciocutané prélevé sur une extrémité a facilité la préservation de la longueur du moignon de l'amputation transmétatarsienne de l'autre extrémité

his feet. He underwent guillotine amputation to just above his ankle, of the left leg, and of his distal foot on the right side (Figure 1). He was transferred to the hospital for closure of the wounds. The plan was to perform a below-the-knee amputation on the left side and use the available tissue from the distal leg, transferred as a free flap, to cover the transmetatarsal amputation stump on the right foot. A fasciocutaneous flap was designed based on the peroneal vessel (Figure 2) and then transferred as a free flap to the foot using the anterior tibial vessel as the recipient vessel for end-to-end anastomosis (Figure 3). The flap provided good contour with stable coverage for prosthesis for ambulation (Figures 4 and 5 ).

\section{DISCUSSION}

The rationale for repair or reconstruction of a lower extremity injury includes length preservation for ambulation and weight bearing. During amputation, the objective is to create a viable, functional residual limb to maximize patient mobility and independence. Extensive loss of skin and soft tissue after these injuries may make it difficult to fashion an amputation stump that will readily tolerate a prosthesis. When part or the entire fore part of the foot is lost to trauma, every attempt should be made to preserve as much foot function as possible (2). Transmetatarsal amputation is more disabling than simple toe amputation, as there is no need for a prosthesis other than a shoe filler in the toe amputation. The loss of push-off, in the 


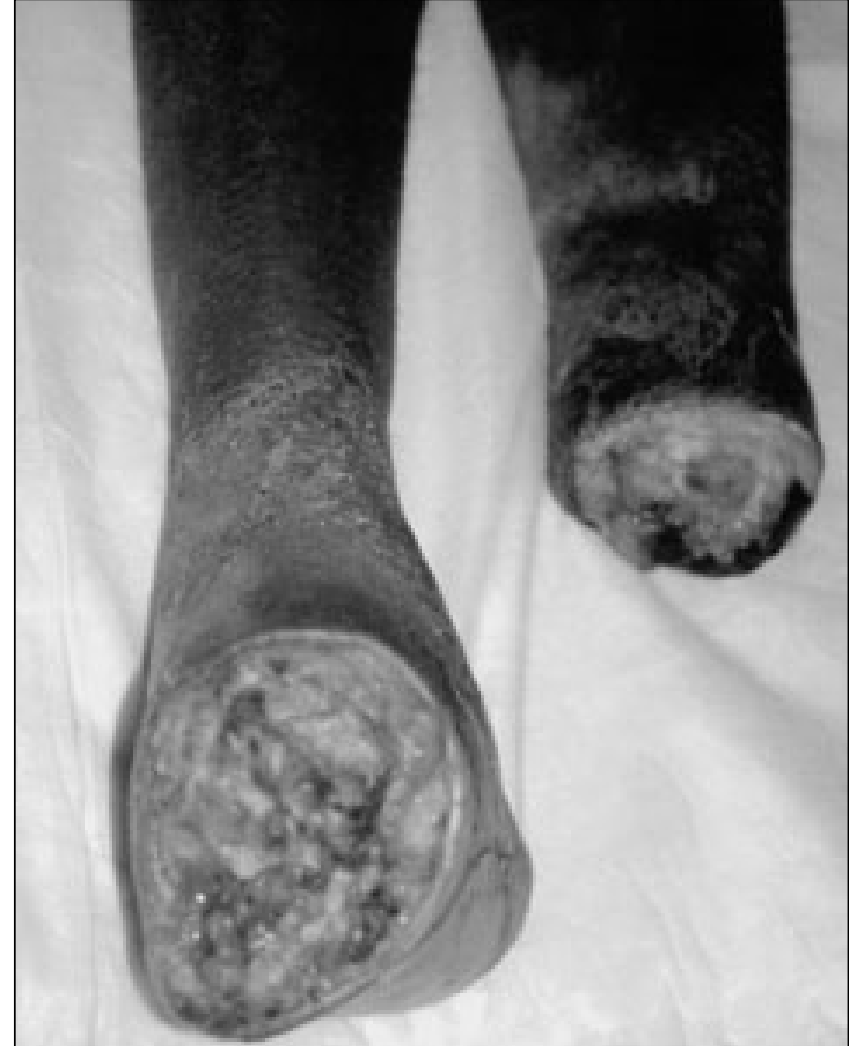

Figure 1) Bilateral lower extremity amputations

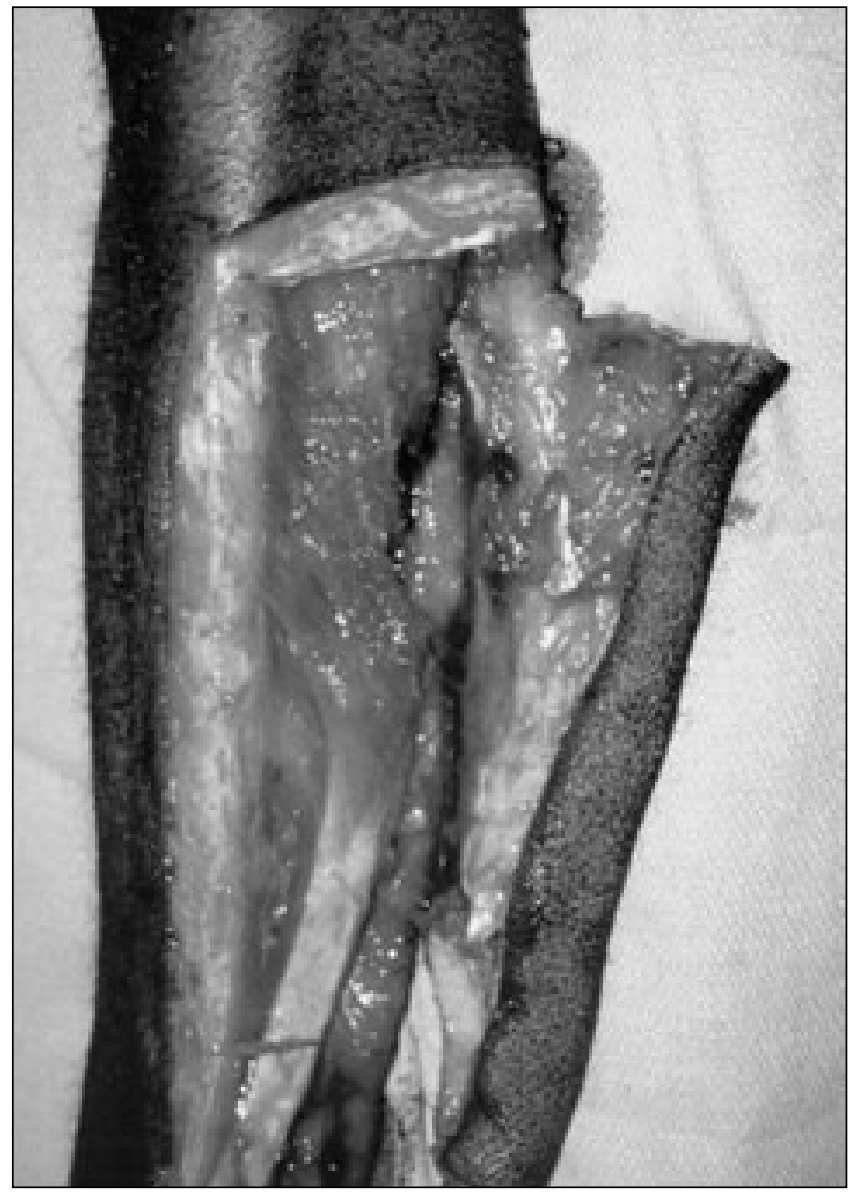

Figure 2) Flap raised before conversion to a below-knee amputation

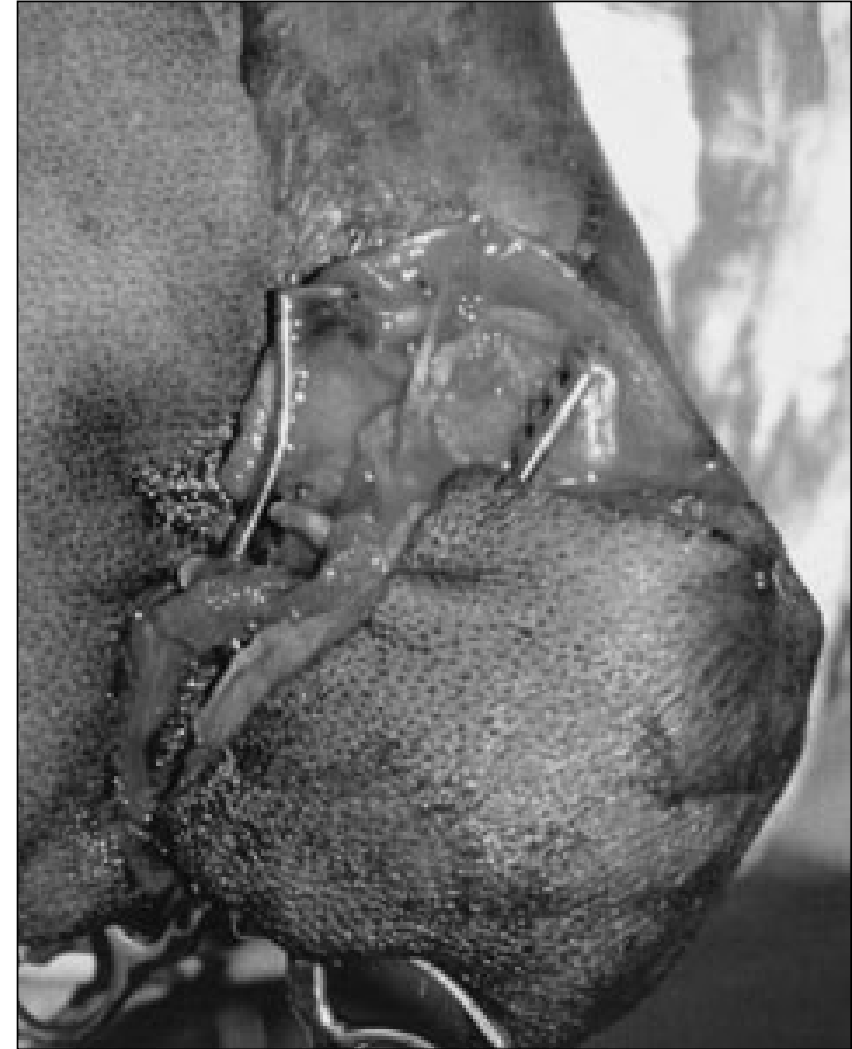

Figure 3) Flap transferred to cover the partial foot amputation

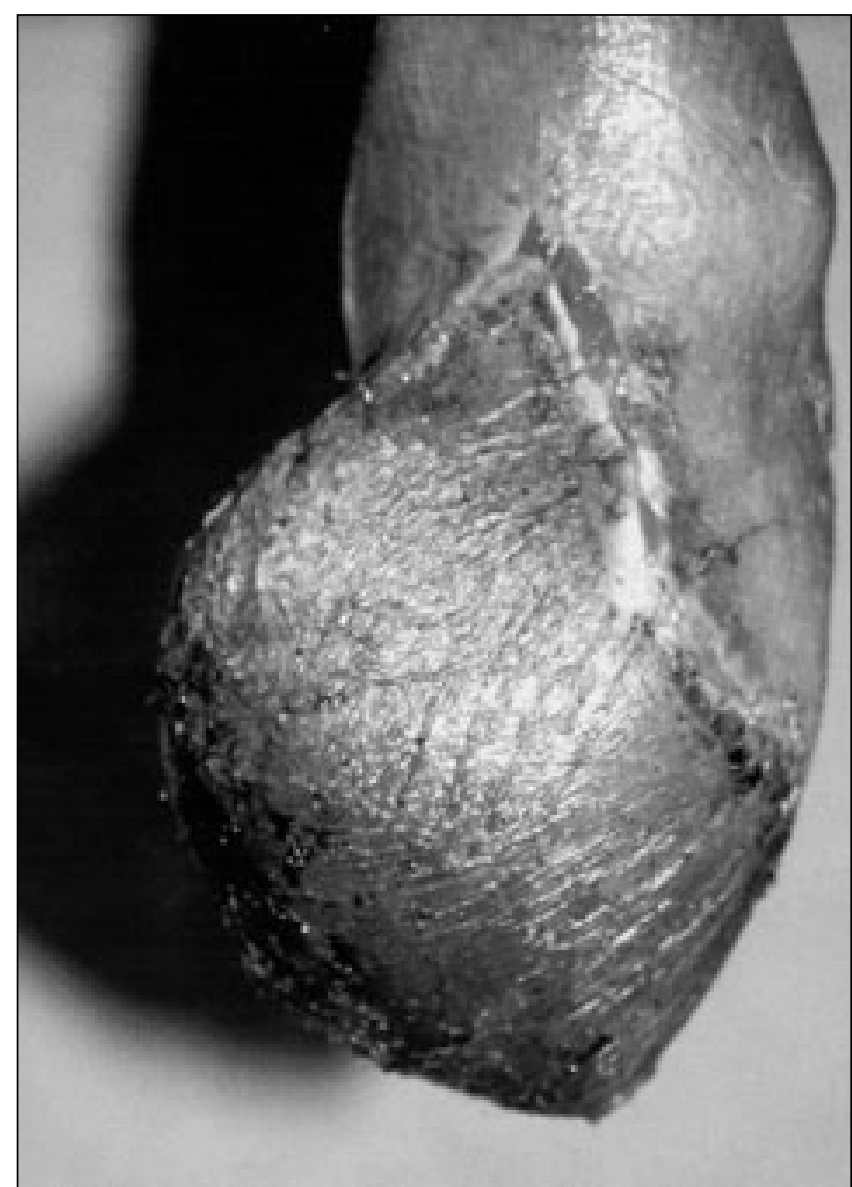

Figure 4) Flap coverage of the foot 
absence of a positive fulcrum in the ball of the foot, is chiefly responsible for impaired gait. Amputations proximal to the transmetatarsal level often result in considerable gait problems during walking. These amputations, commonly known as Lisfranc and Chopart amputations, often have a tendency towards an equines deformity from the loss of dorsiflexor attachments. The arch of the foot may flatten out over time, causing further weight bearing problems. In severe cases (3), such deformities may require amputation at a higher level. Although transmetatarsal amputation for peripheral vascular disease has been reported (4) with poor outcome, a healed transmetatarsal stump preserves foot function, is cosmetically acceptable and does not require a prosthesis.

Tissues from the amputated or nonsalvageable limbs may be used for reconstruction of complex defects resulting from tumour or trauma. Fillet flaps are axial pattern flaps that can function as composite tissue transfers. These can be used as pedicled or microvascular free tissue transfers. This spare part concept is beneficial as long as there is tissue available to harvest in the part to be discarded. Due to the serious nature of the injury and the condition of the patient, this concept is usually overlooked. The fillet flap reconstructions should be integrated into each trauma algorithm to avoid additional donor site morbidity and to facilitate stump length preservation or limb salvage (5-7).

Amputated sole of the foot has been used as a fillet flap to preserve tibial length and optimal stump coverage during primary amputation in a young adult. The foot fillet flap, pedicled on the tibialis anterior vessels, preserving the deep plantar, first dorsal metatarsal and anterior communicating vessels, can be used for successful prosthetic adaptation (8). Every attempt should be made to preserve an adequate stump length, particularly in young patients, to enable the proper fitting of the prosthesis. This may be achieved by free tissue transfers or by using uninjured spare parts from the amputated extremity $(9,10)$.

In this young adult, who sustained crush injuries of both feet, there was no uninjured soft tissue available for adequate coverage of the transmetatarsal stump. Hence, the decision was made to salvage a flap before revision amputation of the other lower extremity and transfer it as a free flap to cover the transmetatarsal amputation of the right foot. Because a sensate heel pad was available, soft tissue coverage of the stump avoided the need for a transtibial amputation.

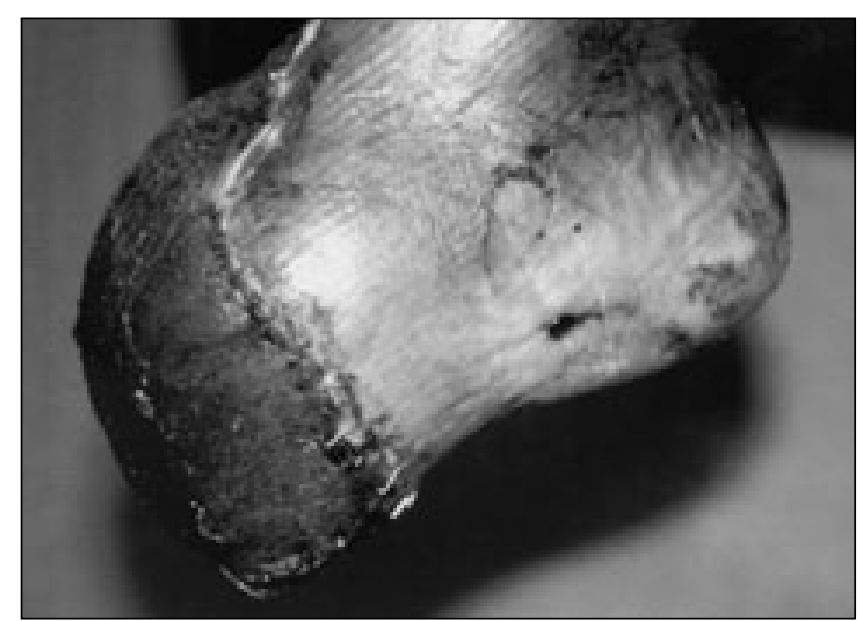

Figure 5) Flap coverage of the foot

\section{REFERENCES}

1. Isik S, Guler MM, Selmanpakoglu N. Salvage of foot amputation stumps of Chopart level by free medial plantar flap. Plast Reconstr Surg 1998;101:745-50.

2. Early JS. Transmetatarsal and midfoot amputations. Clin Orthop Relat Res 1999;361:85-90.

3. Hodge MJ, Peters TG, Efird WG. Amputations of the distal portion of the foot. South Med J 1989;82:1138-42.

4. Sanders LJ. Transmetatarsal and midfoot amputations. Clin Podiatr Med Surg 1997;14:741-62.

5. Kuntscher MV, Erdmann D, Homann HH, Steinau HU, Levin SL, Germann G. The concept of fillet flaps: Classification, indications, and analysis of their clinical value. Plast Reconstr Surg 2001;108:885-96.

6. Weinberg MJ, Al-Qattan MM, Mahony J. "Spare part" forearm free flaps harvested from the amputated limb for coverage of amputated stumps. J Hand Surg [Br] 1997;22:615-9.

7. Chernofsky MA. Upper extremity salvage with free ulnar forearm flap from the amputated part: Case report. J Trauma 1993;34:450-2.

8. Cavadas PC, Baklinska MI, Soler S, Navarro A. Pedicled foot fillet flap based on the tibialis anterior vessels: Case report. J Reconstr Microsurg 2002;18:87-9.

9. Tukiainen EJ, Saray A. Kuokkanen HO, Asko-Seljavaara SL. Salvage of major amputation stumps of the lower extremity with latissimus dorsi free flaps. Scand J Plast Reconstr Surg Hand Surg 2002;36:85-90.

10. Erdmann D, Sundin BM, Yasui K, Wong MS, Levin LS. Microsurgical free flap transfer to amputation sites: Indications and results. Ann Plast Surg 2002;48:167-72. 